\title{
The Mediatization of "SARA" Conflict in Indonesian Online Media
}

\author{
Eni Maryani , Detta Rahmawan, Irma Garnesia
}

\author{
Ilmu Komunikasi \\ Universitas Padjadjaran
}

\begin{abstract}
This study aims to analyses the news on "Aksi Damai" or "Peaceful Protest" occurred on December 2, 2016, in Jakarta related to the incumbent Jakarta Governor, Basuki Tjahaja Purnama or Ahok, over a blasphemy case. The "212 Peaceful Protest" is a protest conducted by several hardliner Muslim groups against Ahok, a Chinese Christian. Ahok was accused of a blasphemy-related to his statements about politicians who exploit a verse from the Holy Qur'an, to win the elections. The study uses a concept of mediatizations with quantitative and qualitative methods to collect data through content analysis, observation, and interviews. The research subject is two online media in Indonesia, Republika.co.id and Metrotonews.com. The news from Republika.co.id and Metrotonews.com are being collected from November 28 to December 4, 2016. In Indonesia, Republika.co.id is considered as a media that is oriented toward Muslim agenda, while Metrotonews.com is oriented toward nationalism agenda. The results show that both Republika.co.id and Metrotonews.com build a media logic or mediatizations related to Ahok's blasphemy cases. Republika.co.id emphasizes a narrative on divinity and piety logic, while Metrotonews.com builds a narrative on the importance of national unity and legal political logic. The substance this study can be concluded that efforts to disseminate the values of tolerance and appreciate the noble values of humanity in a multicultural society must be carried on.
\end{abstract}

Keywords: Mediatization, Online Media, Islam, Conflict, Politics

\section{Introduction}

Indonesia is an archipelagic island country with the total population estimated to reach 261 million (The World Bank Data n.d.). The country is comprised of multicultural societies from ethnicity, religion, race and intergroup relations as well as economic status, political orientation, and various interest. Furthermore, the notion of diversity is known by the term "SARA" (Suku, Agama, Ras, and Antar golongan) or Ethnicity, Religion, Race and Intergroup Relations.

Indonesia has thousands of ethnicities; precisely 1340 ethnic groups (Statistik 2010). The Javanese tribe is the largest percentage (40.2\%), followed by the Sundanese (15.55), Batak (3.58\%), Madura (3.05\%), Betawi (2.88\%), Minangkabau (2.73\%) Bugis
(2.69\%) and Malay (2.27\%) (Kingsbury 2003). Besides, some dwellers have come and settled in Indonesia for hundred years such as Arab descent (2.20\%) and Chinese (1.20\%) (Statistik 2010). Indonesian is also derived from four races such as Mongolian, Melanesian, Negroid, and Veddoid (Capelli 2001).

The religious systems are comprised of a wide variety of beliefs, such as Islam, Protestantism, Catholicism, Hinduism, Buddhism and Confucianism (Yang 2005). Social, economic and political background also forms a set of hierarchical social categories. In its history, the founding fathers have decided that the state ideology should encompass and shelter the whole spectrum of Indonesian society (Hudawati 1995). Subsequently, the urge to unify this 
country also has led to the formulation of national motto Bhinneka Tunggal Ika, which can be defined as unity in diversity. The founding fathers promulgated Pancasila as the foundational philosophical theory of the Indonesian state. Pancasila composed of five principles, that are inseparable and interrelated, such as Divinity, Humanity, National Unity, Democracy, and Social Justice. The Constitution of Indonesia of 1945 stipulated the Pancasila as the fundamental principles of the Independent Indonesia. Moreover, Pancasila is believed to influence the shared values among Indonesians.

In its journey, Indonesia encounters a variety of conflicts which occur between religious adherents and tribes. It becomes a compelling circumstance in this country. Hence, the authorities generate certain efforts, prevailing current policies, and reenacting provisions related to "SARA" (Ethnicity, Religion, Race and Intergroup Relations) to diminish certain conflicts in the future.

Certain issues related to "SARA" usually arises from sentiments of identities concerning of heredity, religion, ethnicity, race and social classes. Such identity sentiments often result in discrimination and even acts of violence. This attitude and action harm the agreement as an independent and sovereign multicultural nation which aims to fight for the just and prosperous society despite its religious view, race, and intergroup relations.

At present, "SARA" conflict in Indonesia is not only triggered by direct interaction but also occurs and generates through the media. Media coverage often disseminates information and creates a perspective which leads to the conflict itself.

This research explores the mediatization process through two online medias with distinctive business ownerships and ideologies in how they cover the "212 Peaceful Protest". We aim to compare both the political interest and the ideology brought by Metrotvnews and Republika on its coverage in 212 Peaceful Protest. Thus, the basic question underlying on this research is how those media construct the logic, influence the political elite, and shape audiences' view regarding the Peaceful Protest in the context of Jakarta Gubernatorial Election 2017.

\section{The Concept of Mediatization}

Mediatization is a word that has its origin in German, mediatisierung (Livingstone 2009). It is a term used in communication studies or media studies to describe a process in which modernity is shaped (Krotz 2008). In this framework, an basic aspect of modernization is the development of media, beginning with a change in communication media and proceeding to the subordination of the power of prevailing influential institutions (Hjarvard 2008). This situation is best described as mediatization in which the institutions and whole societies are shaped by and dependent on mass media (Gianpietro Mazzoleni 2010). Nowadays, the concept has evolved to focus not only on media effects but also on the interrelation between the change of media communication and sociocultural changes as part of our everyday communication practices and our 
communicative construction of reality.

The concept of Mediatization has been used in numerous contexts to characterize the influence media exert on a variety of phenomena. There has been a shift of media's role from a mere companion to the powerful and independent institution of its own. In the past, the media was guided and dominated by the elites of the society. Then, society becomes more literate and the media serves as part of everyone's life due to its convenience, affordability, and dynamic. It became a dominant institution to rely upon which resulted in a new shift of paradigm where everything is now "mediated."

\section{Mediatization in Politic}

The concept of mediatization has long been used to describe the expansion of media logic towards politics as well as the dependency of the politicians and those in authority to the media (Strombach 2008). Mayer (2002) suggests this phenomenon as a mediacracy to describe the practice of media colonisation in politics (media steering politics). Furthermore, Hjarvard (2008) mentions that the expansion of media logic not only happens in politics, but also culturally affects the other social institutions, such as religious view, education, and even family.

This concept was originally used to explain how media is equipped with political communication and some aspects of politics. It demonstrates how the political system is influenced by and adjusted to the demands of the mass media in their coverage of politics (Hjarvard 2008). For instance, political candidates often harness the media to convey political messages to the public, in the way that the message would sound nice on the media.

To address the process of political mediatization, Strombach (2008) suggested four phases in analysing the mediatization process. Firstly, the mass media initially became a tool for politics, the medium for political institutions to disseminate their interests. Secondly, the media becomes a tool to spread particular political interests massively. It is an early phase when people perceive the importance of the media as a necessary source of information which has a powerful impact, the condition called as the first phase of mediatization (Strombach 2008).

On the second phase of mediatization, the media exempted themselves from the government. The media is constantly trying to escape the regime's clutches and try to map its direction through professional rules. Nevertheless, the media will not be independent of the political realm, because it still prevails within limits. This second phase draws a transition from the first phase.

At the third phase of mediatization, the media becomes more independent prior to the second phase. Media continues to move toward professionalism and establishes itself as an economically independent institution with a growing market. Political institutions and elites began to embrace media to thrive their success. Media logics continues to be internalised in politics until the political institutions and elites perceive how the media shape people's conceptions of political reality. This situation is marked 
by the incessant start of political institutions and actors utilising the media in political campaigns or creating press releases to establish an image.

Sooner or later, the media logic is profoundly internalised in political logic. That is the sign where the fourth phase of mediatization has prevailed. Political institutions and elites realise that they could not only use the media to perform their political campaign, but also to formulate policies. In fact, it is important for political cadres to deal with the media and have the ability to spin the argument in the media debate (Jay G. Blumler 1999).

After the transition to Era Reformasi (Post-Soeharto Era), the mediatization phase in Indonesia is at the third and final phase. The third phase indicates the dominance of media logic over the political logic. Political institutions and elites are working with the media to gain a successful political career and utilise mass media for campaigning.

Furthermore, media logic is also related to the process and assumption in the construction of messages through certain mediums, particularly communication technology breakthroughs (Altheide 2004). It defines the media logic in its function as a "medium" to construct the message, and to some degree, its function as the medium can be considered as the "message" itself (McLuhan, 1995).

\section{Political Economy of Media}

In political economy approach, media ownership has a pivotal meaning to witness the role, ideology, media content and effects generated by the media. Different media owners certainly affect media content as well as its effect on the audience.

According to Giddens (Giddens 1999), media conglomerates hold an enormous power which has not able to "be subdued" in democracy. Golding and Murdock (1993) even see a direct relationship between ownership and control. Even the media owner, according to Meier, can play a significant role in legitimising income inequality (wealth), power and privilege.

On the implication, media elites often intersect with power. These industry business elites are closely linked to the power holders. However, this situation indirectly implies the content of the media on what value does their political elites hold.

Political interests in influencing the media in reporting on an issue were also revealed in Wulandari's research related to the Jokowi and Jusuf Kalla governments. Through Robert Entman's framing analysis, her research found how the media preserved Jokowi-Kalla's performance in the first year of their administration (Wulandari, 2016).

\section{"SARA" in Chinese Sentiment, Religion and Political Ideology in Indonesia.}

"SARA" (Ethnicity, Religion, Race, and Intergroup Relations) are perspectives and actions based on sentiments of identity with concern on heredity, religion, nationality or ethnicity and class. Any act involving violence, discrimination, and harassment based on self-identity and class can be presumed as the act of "SARA" (Mantra 1980).

Referred to Mantra (1980), "SARA" can be classified into three categories; 
Individual, institutional, and cultural. Individual categories are acts of "SARA" performed by persons or groups. Included in this category are acts or statements that are offensive, intimidating, abusive and insulting both identity and class.

Institutional Category is an act of "SARA" performed by an institution, including the state, either directly or indirectly, intentionally or unintentionally, which has made discriminatory rules in the organisational structure and policy. The last category, namely cultural, is the spread of myth, tradition and discriminatory ideas through the cultural structure of society.

Issues related to "SARA" conflict in Indonesia are often linked to the Chinese community. Chinese have settled in Indonesia for centuries. Many of them later married residents. They also contribute to creating local traditions and cultures in this country which formed the Sino-Indonesian culture. The Chinese community itself, as excerpted from the Chinese-Islamic-Javanese Flow (Qurtuby 2003), played the role as the "cocreator" of various traditions and cultures in Indonesia such as food, beverages, clothing, arts, medicine and treatment, and the shipping system. However, their presence has not been fully accepted by some people in the country.

The recent and most significant antiChinese sentiment took place during the May 1998 tragedy. At that time, there was an enormous news regarding the Chinese victims; pillage and persecution were everywhere. Historically, anti-Chinese sentiments have occurred long ago and in this country. The Java War (1825-1830) was one example of anti-Chinese sentiments that took place in the pre-independence phase of Indonesia. In 1916, anti-Chinese riots also exploded in Kudus as Tan Boen Kim wrote in his classic book, Peroesoehan di Koedoes or Commotion in Kudus (1918) (Qurtuby 2017).

After nation's independence, violence against Chinese citizens also took place in 1946-1948, and 1963 during the Old Order of Soekarno. During the New Order of Soeharto, Chinese experienced even the peak of suffering. They are accused of being the culprit behind PKI (The Communist Party of Indonesia) (Qurtuby 2003). The state repressively suppressed Chinese with certain discriminatory policies such as the Chinese newspapers ban or requiring an Indonesian Citizenship Certificate.

Conversely, religious sentiments in Indonesia, with Muslims as the majority, is relatively rare or not being exposed to the public. Among the religious conflicts that ever occurred, the longest and the most significant one was the conflict between communities of Muslim and Christian in Ambon. Sometimes, the conflict in each unity also happens. For instance, the SunniShia dispute or Ahmadi Muslim and nonAhmadi Muslim dispute.

At present, conflicts between political cohort are often occurred, particularly with the regional elections. The large-scale conflict in political groups happened at the end of the old order to the new order when some political party adopted communism as its ideology. The dispute was widening 
towards religious and non-religious views which caused the hustle and bustle because of the misleading information that oppressed artists, academics, labourers, and others considered being affiliated with PKI (The Communist Party of Indonesia).

Conflicts related to ethnicity, religious view, and political beliefs are intertwined that they cannot be understood separately. For example, Chinese tribe as a non-Muslim migrant have more conflicts with indigenous groups than Arabs Muslims. However, both tribes are still exclusive culturally (some tend to marry their group) and have many differences with the indigenous people. In a word, political interests are presumed to be the primary cause of ethnic or religious disputes such as Ambon conflict and some cases in the regional election or Pilkada.

This study aims to analyses the news on "Aksi Damai" or "Peaceful Protest" occurred on December 2, 2016, in Jakarta related to the incumbent Jakarta Governor, Basuki Tjahaja Purnama or Ahok, over a blasphemy case.

\section{Method of Research}

This research examines Republika and Metrotvnews coverage on 212 Peaceful Protest as a case regarding Jakarta Gubernatorial Election 2017. We want to explore the logic of 212 Peaceful Protest built by those two medias. The logic that subsequently influenced how society responds to the blasphemy case brought by Basuki Tjahaja Purnama in the extent to Jakarta Gubernatorial Election 2017.

The case study with both quantitative and qualitative approach is used in this research, followed by content analysis, observation, and interviews as the data collection technique. On the beginning, we gathered the coverage from both online media from November 28th to December 4th, 2016. Subsequently, we identified large amounts of textual information of the Islamic Peaceful Protest from the two medias. We conducted the content analysis through the title, topic, variety of influencers, message orientation, and quantity of coverage. Afterward, we conducted the interviews to nine informants; media experts, political experts, and the public who voted in Jakarta Election. To perform further analysis, the data were combined with literature study regarding the insight and strategy used by the candidates, its political party as well as the campaigners.

\section{Result and Discussion}

\section{Ahok Case and the Emergence of "SARA" Conflict}

The dispute originally started when Basuki Tjahaja Purnama, known widely as Ahok, angered many after he refered a Koranic verse while on the campaign trail in Kepulauan Seribu or Thousand Islands in September 2016 (Henschke 2017). He complained about the politicisation of Quran letter of Al-Maida verse 51. In his campaign, he told voters that they should not be duped by religious leaders who use the Holy Quran to justify the claim that Muslims should not be led by non-Muslims. The official encounter was uploaded on Jakarta Federal Government's website. However, then, a man named Buni Yani edited the transcript of the video and uploaded the edited 
version on social media, displaying Ahok offending Islam using Al-Maida verse 51. In consequence, the video of his speech went viral and caused public uproar. The case snowballed and heightened the tension of Chinese sentiment as Ahok is an indigenous Chinese. Tensions have continued to rise coupled with the conflicts from supporters of Ahok and Anies, in Jakarta Gubernatorial Election.

\section{Charge on Ahok Blasphemy Case}

Ahok explained on his Instagram account $(10 / 06)$ that he did not intend to insult Islam, but the hardline Islamist groups kept reporting him to the police. As referred in BBC (10/07), The Indonesian Council of Ulama (MUI) South Sumatera Based has reported Ahok on suspicion of blasphemy in Thursday (10/06) coupled with the report from FPI SecretaryGeneral, Habib Novel Chaidir Hasan.

Ahok was charged with a Criminal Justice Act Article 156a juncto Article 28 (2) no. 11 of 2008 on Electronic Transactions and Information (ITE) with five years' detention charge. Besides Indonesian Council of Ulama (MUI), the group of lawyers from the Advokat Cinta Tanah Air (ACTA) also handed the report over the blasphemy case to the Elections Supervisory Body (Bawaslu). The incumbent governor was allegedly failed to interpret Al-Maida 51 as he is a non-Muslim. As a result, the police have received 14 reports regarding the case from the hardline Islamist groups. Subsequently, Indonesian Council of Ulama (MUI) released the statement that Ahok had caused religious defamation and insulted both the Quran and ulemas.
On the other hand, the dispute has continued to arise involving Ahok's supporters, non-Muslims, and Chinese people. The slow investigation process even angered the hardline Islamist groups which made them rally the masses to show the demands of the public against the legal process of Ahok case.

\section{Ahok-Djarot Successfully Entered The Sec- ond Round of the Regional Election of Jakar- ta}

Ahok-Djarot occupied the first position in the first round of regional election of Jakarta $(42.99 \%)$, followed by Anies Baswedan-Sandiaga Uno in the second place (39.95\%), and Agus Harimurti Yudhoyono-Sylvi on the third place. Based on its percentage, Ahok was elected not only by non-Muslims but also by Muslims for several reasons. Firstly, Some Muslims clearly do not buy the propaganda that non-Muslims cannot be elected as a leader. Secondly, Ahok successfully led Jakarta to the better place despite being harsh and arrogant. Thirdly, Ahok has won plaudits for combating corruption from low level of Jakarta authorities to the member of Regional Representative Council (DPRD). To top it all off, Ahok was the most qualified candidate prior to his credentials.

While some people believe that religious view is not the primary reason for people not to elect Ahok, it is also the most tantalising issue on public debate. There is speculation on why Ahok lose his votes. Firstly, people presumed that Ahok does not reflect the way of being a good leader and that he does not empower a good communication style. 
Secondly, he is perceived to have crucial role in Jakarta's land reclamation. Thirdly, Ahok's decision towards evicted residents has been facing sharp criticism from people, suggesting that he does not consider the sociological and psychological aspect in a community. He frequently that 'insists' evictions must go ahead despite the resident rejecting it.

People worried about a possible violent backlash from the losing side in the Jakarta Gubernatorial Election. Provided the fact that Ahok was standing trial on blasphemy charges and opposed by Islamist hardliner groups. It was a terrible moment for different religious adherents. Regardless of the situation, media played an important part as its coverage could trigger the dispute or increase escalation of conflicts to a higher level.

\section{Mediatization of Ahok Blasphemy Case through Republika.co.id and Metrotvnews. com}

The Blasphemy case related to Ahok, has attracted public opinion and is being categorised to "SARA" case. The case has morphed to religious sentiment and polarized narratives of Muslim versus nonMuslim, "Chinese descendants" versus "Native Indonesian", and over the political supporter of Ahok and Anies Baswedan. To deeply understand how media construct the political logic over the blasphemy case and "SARA", we will explore the coverage from republika.co.id and metrotvnews.com.

\section{Republika as a Muslim Community Online Newspaper}

Republika is a national newspaper which originally came from the idea that
Muslim Community should have a media which describes their interests. At that time, Kompas, Suara Pembaharuan (Christian) and Merdeka (Socialist) dominated the business on its field. The publication of this newspaper has remarked the culmination of a long-standing effort among Muslims, especially young professional journalists led by former Tempo Newspaper reporter, Zaim Uchrowi. Indonesian Muslim Scholars Association (ICMI), which was led by BJ. Habibie, also played a big contribution to the establishment of this newspaper. Republika's first edition was published on January 3, 1993, after they got the publication permit issued by the government.

Republika never experienced a change in its vision and mission even after couple times change management. Its vision is Modern, Moderate, Muslim, Nationality, and Democratic. In line with its mission as an advanced, intelligent, and civilised public newspaper. Over time, the business advanced has strengthened the newspaper independence. Hence, Republika becomes more professional and mature as a daily newspaper for the Muslim community.

Furthermore, Republika released the online version http://www.republika.co.id/, which will be analysed further, since August 17, 1995. Republika Online (ROL) is a news portal served in text, audio, and video.

\section{Metrotvnews as a Newspaper with National- ist Brand}

Metro TV is the Indonesia's first 24-hour news channel. The station was established on 25 November 2000 by PT Media Group which is owned by Surya Paloh. Surya 
Paloh is the founder and Chairman of the Democratic Nationalist Party (Nasdem). Coupled with the Media Indonesia daily and Lampung Post, these newspapers and TV Station, are part of the Media Group.

PT Media Televisi Indonesia obtained a broadcasting license with the born name "MetroTV" on October 25, 1999. On November 25, 2000, MetroTV first aired in a test of transmission in 7 cities. Initially, it only broadcasted 12 hours a day, but since April 1, 2001, MetroTV began airing for 24 hours, making itself as the first TV station in Indonesia that broadcast for 24 hours.

Metro TV has a different concept than other stations, besides broadcasting for 24 hours, it focuses only on the news program. However, on its development, the station is also inserting elements of entertainment in its programs, albeit it remains in the news corridor. MetroTV is also the first station to broadcast the news in Mandarin: Metro Xin Wen, and also the only TV station which does not broadcast the soap opera. Furthermore, MetroTV also aired the first English-language international broadcast in Indonesia, Indonesia Now, which can be watched from around the world. In consequence, this station is known to have lots of news presenter in Indonesia. To exemplifies, the online version of MetroTV, namely http://www.metrotvnews.com/, presents a printed version of its broadcast on television.

\section{The Integration of Media Coverage and Po- litical Activity}

The regional election in Jakarta becomes dynamic in politics since Jakarta is the capital of this country which known as the most populous city and the centre of business, politics, and culture. As a result, Jakarta gubernatorial election has attracted much attention and become a prominent issue on the national scale.

Originally, there are two candidates in the election which have the affiliation with the media that later becoming their tool's campaign. The two candidates, Ahok-Djarot and Anies-Sandiaga, brought two different kind of reporting from MetroTV and Republika. As a result, political campaigns that should expose the skills and credibility of the two candidates turned into political beliefs and religious sentiment.

\section{When The 212 Peaceful Protest Becoming a Part of Political Activity in Jakarta Guber- natorial Election}

The legal process regarding the blasphemy case by Basuki Tjahaja Purnama has taken much attention and hoped to acquire a fair law. Lately, the case has brought the Peaceful Protest involving the large-scale public movement. Many have got different estimations regarding the number of the participants with some claims boasted that there are 4, 7, or even 12 million participants. The movement frequently centered in the National Monument (Monas), Jakarta.

\section{Struggling and Countering The Law at The Same Time}

The 212 Peaceful Protest was an extended protest to the previous rally on November 4, widely known as 411 Protest. Despite the transparent and objective investigation to Ahok, the distrust over law enforcers has developed. Therefore, the antiAhok groups kept mobilising the masses 


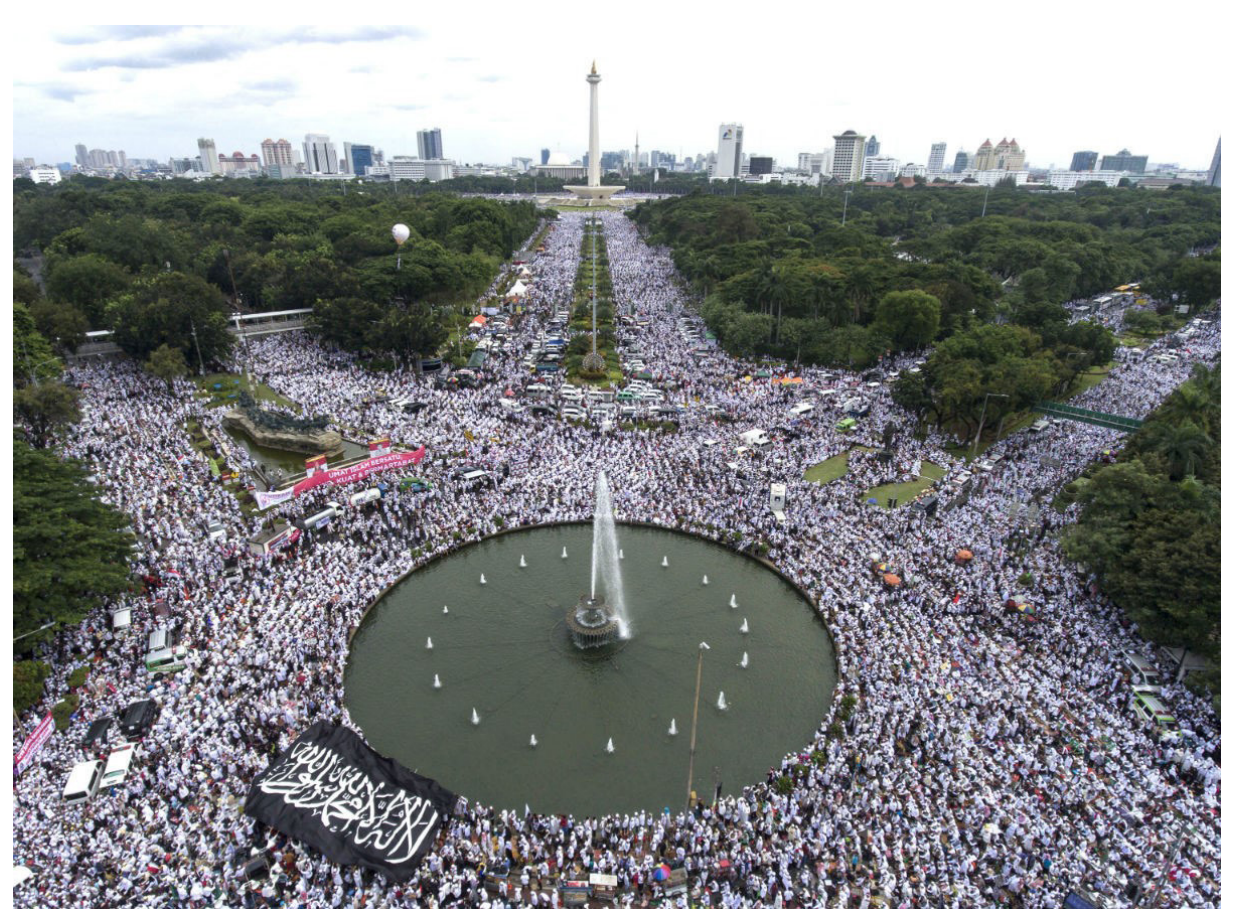

Figure 1: Aerial Photos of "Peaceful Protest 212". Source: Antara Foto/Sigid Kurniawan https://beritagar.id/artikel/berita/aksi-damai-212

on the streets demanding for the fair law of Ahok's blasphemy case. The protestors expected the law enforcers to work fast and carry out the fair prosecution of this case.

Meanwhile, some groups that against the anti-Ahok hardliners presumed that the legal process had been tainted by public pressure as visible in two massive rallies which reflected the unfair treatment to Ahok as a suspect before the court hearing (The Jakarta Post, 2016). They deduced that the mounting public pressure would affect the investigation and the prosecution which subsequently found Ahok guilty based on the intimidation of public pressure rather than considering current laws. They thought that the protests were not only about justice but also to found Ahok guilty and put him imprison. Besides, the large-scale movement tends to assigned Ahok as a blasphemer who should be convicted.

\section{Tafsir of Al-Maida: We May Or We May Not Elect Ahok-Djarot}

The 212 Peaceful Protest, which was initially declared as an attempt to execute the legal procedures of religious defamation, was ultimately considered to have been used as a tool for disseminating the meaning of Al-Maida's verse regarding choosing the leader. The conservative groups interpreted the verse as a hint for not choosing the nonMuslim candidate. Consequently, there has been a widely circulated opinion that Muslims may not elect Ahok-Djarot in the Jakarta Regional Election, and should elect Anies-Sandiaga instead. If Muslims ever question this tafsir, their faith should be questioned.

There has long been a variety of religious groups in Indonesia which interpret the Koranic verse and Hadist with a different version. Hence, they implement the beliefs 
and conduct the ritual pray differently. Even though the majority of Indonesian is Sunni, there have been three different groups in Indonesia which perform the Islamic rituals differently. They are Muhamadiyah, Persis, and Nadhatul Ulama. For instance, there has always been a different way of determining the Eid al-Fitr in Indonesia, both from Muhammadiyah and Nahdhatul Ulama Ulama. Muhammadiyah comes up with Wujudul Hilal while Nadhatul Ulama tends to use Imkanur Rukyat to decide when the Eid al-Fitr is.

Every year, the government announces Eid al-Fitr based on a meeting with every religious group. However, the government does not oblige the citizens to celebrate the Eid al-Fitr on the day the government decides. The Eid al-Fitr celebration does not imply someone's faith or even becoming a conflict between the two religious groups. The festival date does not mean that a person being less nationalist if they do not celebrate the same day as the authority does. Muslims celebrate the festive peacefully, and they get along even when they celebrate Eid al-Fitr on a different day.

Back to the case with Al-Maida verse, the different interpretation regarding Al-Maida verse has been generating various views whethera Muslim may or may not elect AhokDjarot. There is no official statement from the government regarding this interpretation and its link to the election. However, those interpretations, which should be a personal standpoint, has grown as a conflict of beliefs rather than just a misleading conception. In consequence, the different viewpoint has led to the different supporting group, AhokDjarot or Anies-Sandiaga.

\section{Muslim Against Non-Muslim or Infidel}

The conflict got worse when the people who intended to elect Ahok-Djarot was perceived as an infidel or 'kafir,' this is outrageously offending someone's principle and beliefs. It means that a person who took a different perspective in viewing Ahok-Djarot as a better candidate is assumed as infidel or kafir. Even though they are not rejecting the faith of the Quran, they just have different points of view related to the meaning of leaders based on Al-Maida verse. They also got a different perspective regarding who is deemed worthy and competent to serve Jakarta.

When some Muslims who support Ahok was asked about electing a non-Muslim leader, they argued that Ahok was not going to reign Indonesia, he is not in the highest position of the authority. Indonesia still got the head of People's Representative Council (DPR), Regional Representative Council (DPRD), People's Consultative Assembly (MPR), Minister of Home Affairs, or even the President, which all are Muslims. Therefore, there has been a wide range of interpretation regarding 'leader,' that has shaped people's mind in choosing their government. However, the conservative groups still used this case to construct people's mind regarding Jakarta Election which later to determine whether a person is a good Muslim or not.

\section{Nationalist and non-Nationalist}

Conversely, Ahok-Djarot's winning team also brought Al-Maida verse towards the polarisation of being nationalists and non- 
nationalists. The attitude of nationalism was then opposed to the views of the opposing group that rejected Ahok-Jarot. The Muslims who refused to vote Ahok-Jarot were later labelled as non-nationalist and denied diversity. They also later presumed that Ahok's refusal was not solely a case of blasphemy, but there was also about Jakarta reclamation land, a smug leadership style, or some cases of corruption that also linked to Ahok, despite that was not yet proven. Regarding the issue of nationalism, MetroTV referring President Jokowi as a resource by stating that, "Jokowi rings a bell and stating that Indonesia is a diverse nation. In every occasion, Jokowi vigorously conveys the importance of maintaining the diversity of this country."

\section{Media Logic and Political Interest in 212 Peaceful Protest}

The media coverage of Peaceful Protest 212 has not only caused "SARA"-based conflict but also conflicts among political groups. This case became the subject of media coverage which was also used by each political group to lift its ideology and interests onto the public. Both media, whether Republika.co.id or Metrotvnews.com, then synergised with respective political parties, with which they were affiliated, to support their political agenda.

\section{Divinity Logic and Piety Logic Regarding 212 Peaceful Protest}

The news about a group of people from Ciamis, West Java, who marched to Jakarta, was intensely reported by Republika.co.id on December 1, 2016. Doing a protest by walking for such a long distance (ca. 300 $\mathrm{km}$ ) is certainly not common, at least in this country. This rally then turned dramatic and heroic as covered by Republika.co.id. Even though in reality they did not walk along the way, because they took the bus from Bandung to continue their action to Jakarta, Republika. co.id still described this rally as extraordinary. The effort was then perceived as a heroic action in defending Islam, hence widely known with the term 'Defending Islam'.

'Defending Islam' then became a concept that born as a response to what Ahok has done in Kepulauan Seribu, which was popular as the 'Blasphemy Case'. The term 'Defending Islam' coined as the conviction of Ahok's 'Blasphemy Case.' The case wrapped up and has nothing to do with the political interests rather than the Islamic faith of a Muslim who defends his religion. Media coverage and preaching made what Ahok did are harmful to Islam. The agenda leads the public like; as a righteous man, a Muslim must defend Islam by convicting Ahok. Besides convicting Ahok, they also affirm that the election is not only public and political affairs but more importantly, it is a form of human affairs with God. If a person is Muslim and he knows that Al-Maidah is the word of God, then he must not elect Ahok in Jakarta Gubernatorial Election 2017.

\section{Nationalist and Law-abiding Logic Regard- ing 212 Peaceful Protest}

Metrotvnews.com framed the Peaceful Protest with calls and warnings to people to keep their sense of nationalism and obedience to the law. Some coverages included terms such as 'maintaining the diversity of this nation', 'maintaining the unity' and 'Indonesia is ours'. Metrotvnews.com also referred their 
coverage to national figures or government actors such as Indonesian President, ministers, and security forces. Some party figures were taken as news sources like Oesman Sapta (Deputy Chairman of People's Consultative Assembly), Djan Faridz (Chairman of the PPP Party), Setya Novanto (Chairman of Golkar Party), and Surya Paloh Chairman of NasDem Party and the owner of Media Group, the parent company of metrotvnews.com).

Metrotvnews.com's coverages were in line with the stance of Surya Paloh who joined the counter-demo and yelled "Who Are We? Indonesia! Who Are We? Indonesia! We are Indonesia" when greeted thousands of participants of \#KitaIndonesia in Bundaran Hotel Indonesia, Central Jakarta, on Sunday (Metrotvnews, 4/11/2016).

The strategy of selecting the opinion leader in several coverages from Metrotvnews indicates the involvement of the owner and his interests to the way Metrotvnews integrates nationalism in its coverage. The publication of Metrotvnews related to the 212 Peaceful Protest stated that Metrotvnews.com do not support this rally and perceived this rally as the counter-action to nationalism.

Metrotvnews.com also proclaimed the counter-action to 212 Peaceful Protest, namely the 'Nusantara Bersatu' or United Nation (30 November) and \#KitaIndonesia action (December 2nd). The perpetrators of the 212 Peaceful Protest and their supporters on the ground later perceived as people who do not have nationalism and want to demolish Indonesia. The Jakarta Gubernatorial Election framed by Republika.co.id in a religious framework is then wrapped up by Metrotvnews.com as a national problem and endanger the unity of diversity in Indonesia.
Referring to this issue; we have some enticing and prominent points of discussion. As The First Phase of Mediatization, media becomes a tool for political institutions which their coverage needs to be viewed politically. The public then questions the framing of Journalists and their capacity as a neutral source of information as well as their independence towards political affiliation. The process of Mediatization attests that the politicians and their winning team have managed to maximise the use of their media to convey power and political interests. Hence, it is prominent to have a firm media policy to prosecute the media in Indonesia which declaring their political allegiances and collaboration with a particular political group or interest. It means that public should know the political concern of the media tycoons so that they are not politically manipulated. Furthermore, the public should also know which media that has no collaboration with any political cohort so that they can compare this from the affiliated media.

Media policy and public awareness to the political affiliation of the media will encourage the media independence (Second Phase of Mediatization). In this stage, the existence of the media does not occupy as the subordination of the political group, but the Media can also play its part. The media began to be independent of the government or politics but not entirely independent because it still operates within the boundaries of the rules of political institutions. Media is not only a political tool but also directing the political direction of the various issues they covered. At this stage, media has 
ideological powers in the news which have the opportunity to stand on its own. The problem is whether the media chooses or uses its power for public interest related to the concept of 'watchdog' or the fourth pillar of democracy or they use this force for their affairs.

Besides the political interests associated with Republika.co.id and Metrotvnews.com, the other threat to the media is the economic interests. As an economically independent institution, media can be an economic tool for its owner. When this interest arises, the involvement of the media in the political news not only reflects the political orientation of the institution but also relates to its economic interests. Media rackets place itself as a partner of the political party stand for its political and economic interests. The mediatization process reached this stage when the media became a more independent institution. Media is getting stronger so that political institutions and elites start accustoming the media to thrive their business. Media logic continues to be internalised in politics so that political institutions and elites increasingly recognise the importance of media in manoeuvring the politics (Third Phase of Mediatization).

What happened in the Ahok Blasphemy Case and the coverages regarding this issue reflects that media logic is increasingly internalised in political logic. The Head Regional Election or Jakarta Gubernatorial Election strayed off from political concern. Jakarta Election grew into the divinity and piety theme (Republika.co.id) as well as nationalism and the unity of Indonesia theme (metrotvnews.com). Politicians and the winning teams are not promoting their candidates' program or their candidates' credentials, rather than bringing the issues of ethnicity, religion, racial and intergroup conflicts widely known as "SARA" in Indonesia.

Media plays its part and turns this conflict into a profitable business while politicians considered this "SARA" issue as a key matter to attain the victory (Fourth Phase of Mediatization). Both parties, political groups and the media, distancing the Regional Head Election from a democratic political process and serving it as a social, groups, even personal conflicts which attacking personal opinion and excluding all the discussion from candidate's credibility and public interest. The democratic electoral system in Indonesia, where an individual has its political rights, thrives less. Systems that give people the opportunity to use their political right to vote for the best candidate no longer happens. The concept of democracy which often echoed in political education; that democracy is a reflection of power that upholds the principles of the people, elected by the people, and for the people, is merely a slogan of democracy.

\section{Conclusion}

Indonesia's democratic system, recognised as the most democratic country in Asia, is politically threatened by mediatization in media. "The existence of Indonesia as a multicultural society is under threat from political phenomena that exploit issues related to ethnicity, religion, race and among groups (Suku-Agama-Ras-Antar Golongan; "SARA" issues) as the basis of competition in politics. In general, this is a 
social situation that should be scrutinised and anticipated as it will break human efforts to uphold the values of noble humanity.

The process of Jakarta Head Election (as the capital of Indonesia), presents a political battle out of political discussions and public welfare. Jakarta Gubernatorial Election reflects the inter-ethnic, religious, racial and intergroup conflicts rather than exposing the political program and a clear vision of the candidate. The case of Basuki Tjahaja Purnama, known as Ahok's call in the Election of Jakarta, is a proof of the use of "SARA" issues by politicians and the media in their competition.

Based on the analysis through two media, Republika.co.id and Metrotvnews.com, it can be found that those media build a media logic or mediatizations (Livingstone \& Lunt, 2014) through Ahok's blasphemy case. The coverage of these two media made Ahok case centralises more the 212 Peaceful Protest. It makes the Jakarta Head Election was not a just political issue, but wide spreading to issue of the tribe, religion, race, and intergroup relations. The coverage of both media encourages the emergence of chaotic, infidel, and non-nationalist sentiments, which then constructed by the winning teams as political growth. Hence, it can be said that by using the concept of mediatization, the media 'change' the social structure and relationships between audiences

Textually, Republika.co.id builds a narrative that Ahok is guilty of blasphemy case and should be jailed, while Metrotvnews.com builds a narrative on the importance of national unity and supports the legal and political logic regarding Ahok's case. Republika.co.id builds the logic of on divinity and piety logic while Metrotvnews.com builds the logic of national unity and legal political logic. The media coverage encourages the emergence of ethnic, racial and inter-group interest during the election campaign process. Both media coverage also supports politicians using "SARA" issues to win the election.

Based on the analysis in this research, it can be concluded that efforts to disseminate the values of tolerance and appreciate the noble values of humanity in a multicultural society must be carried on. These efforts must be undertaken by the public, communities, political parties, government, and stakeholders in various ways, context, situations and most importantly, economic and political competition.

\section{Reference}

Altheide, David L. 2004. "Media Logic and Political Communication." Political Communication Vol. 21. No. 3 293-296.

Capelli, C., Wilson, J.F., Richards, M., Stumpf, M.P.H., Gratrix, F., Oppenheimer, S., Underhill, P., Pascali, V.L., Ko, T.M., and Goldstein, D.B. 2001. "A Predominantly Indigenous Paternal Heritage for the Austronesian-Speaking Peoples of Insular Southeast Asia and Oceania." American Journal of Human Genetics 432-443.

Gianpietro Mazzoleni, Winfried Schulz. 2010. "'Mediatization" of Politics: A Challenge for Democracy?" Political Communication 16 (3) 247-261.

Giddens, Anthony. 1999. Runaway World: How Globalisation is Reshaping Our Lives, . London: Profile Books.

Henschke, Rebecca. 2017. Ahok trial: The blasphemy case testing Indonesian identity. February 14. http://www.bbc. com/news/world-asia-38902960. 
Hjarvard, S. 2008. " The mediatization of a society: A theory of the media as agents of social and cultural change." Nordicom Review, 29(2) 105-134.

Hudawati, Nannie. , Bahar, Saafroedin. 1995. Risalah Sidang Badan Penyelidik Usaha-usaha Persiapan Kemerdekaan Indonesia (BPUPKI) Panitia Persiapan Kemerdekaan Indonesia (PPKI). Jakarta: Sekretariat Negara Republik Indonesia.

Jay G. Blumler, Dennis Kavanagh. 1999. "The Third Age of Political Communication." Political Communication 16 209-230.

Kingsbury, Damien. 2003. Autonomy and Disintegration in Indonesia. Abingdon: Routledge.

Krotz, F. 2008. " Media connectivity: Concepts, conditions and consequences." In Network, connectivity and flow: Key concepts for media and cultural studies, by F. Krotz \& S.Moores A. Hepp. New York: Hampton Press.

Livingstone, Sonia. 2009. "On the mediation of everything." Journal of Communication, 59(1) 1-18.

Mantra, Ida Bagus. 1980. Beberapa Masalah Penduduk di Indonesia dan Akibatnya di Bidang Sosial Ekonomi. Jakarta: LP3ES .McLuhan, Marshall. 1995. Understanding Media. Massachusetts: MIT Press.

Peter Golding, Graham Murdock. 1993. The political economy of the media. Cheltenham: Edward Elgar.

Qurtuby, Sumanto A1. 2003. Arus Cina-IslamJawa: Bongkar Sejarah atas Peranan Tionghoa dalam Penyebaran Agama Islam di Nusantara Abad XV \& XVI. Inspeal Press : Yogyakarta.

Qurtuby, Sumanto Al. 2017. Sentimen Anti-Cina di Indonesia. January 2. Accessed March 13, 2017. http://www. dw.com/id/sentimen-anti-cina-diindonesia/a-36974659.
Sonia Livingstone, Peter Lunt. 2014. "Mediatization: an emerging paradigm for media and communication studies." Mediatization of Communication, by Knut Lundby, 703-724. Berlin: De Gruyter Mouton.

Statistik, BadanPusat.2010."Kewarganegaraan, Suku Bangsa, Agama, dan Bahasa." www.bps.go.id. https://www.bps.go.id/ website/pdf_publikasi/watermark\%20 Kewarganegaraan, \%20 Suku\% 20 Bangsa,\%20 Agama\%20dan \% 20 Bahasa_281211.pdf.

Strombach, Jesper. 2008. Four Phases of Mediatization: An Analysis of the Mediatization of Politics. London: Sage Publications.

Strömbäck, J. 2008. "Four phases of mediatization: an analysis of the mediatization of politics." International Journal of Press/Politics, vol 13, no. 3 228-246.

n.d. The World Bank Data. https://ata. worldbank.org/country/indonesia.

Thomas Meyer, Lew Hinchman. 2002. Media Democracy: How the Media Colonize Politics. Malden MA: Blackwell.

Wijaya, Callistasia Anggun. 2016. Ahok's prosecutors promise to play fair. December 14. http://www.thejakartapost. com/news/2016/12/14/ahoks-prosecutorspromise-to-play-fair.html.

Wulandari, Theresia.2016. Pemerintahan Jokowi-Jusuf Kalla Menurut Kacamata 5 Media Massa di Indonesia, Jurnal ASPIKOM, Vol.3 no 1, 2016, DOI: http:// dx.doi.org/10.24329/ aspikom.v3i1.102

Yang, Heriyanto. 2005. "The History and Legal Position of Confucianism in Post Independence Indonesia." Marburg Journal of Religion 8. 